\title{
Mass Literature as Experimental Ground for Author's Strategies: the Case of Anna Karenina
}

\author{
Maria A. Chernyak* \\ Herzen State Pedagogical University of Russia \\ 48 Moyka River Embankment, St. Petersburg, \\ 191186, Russia
}

Received 10.01.2017, received in revised form 19.03.2017, accepted 29.04.2017

The article is devoted to the analysis of the representational author's strategies used in the modern Russian mass literature. In the situation when Russian culture has lost the conception of "literature centrism", the analysis of different ways of classical texts appropriation has become rather current. The article deals with the phenomenon of the "game" of the contemporary mass culture with classical literature and the complex of new mythologies emerging as a result. In addition, the article identifies the reasons for the frequency of appeal to Leo Tolstoy's novel Anna Karenina. A wide mosaic of contemporary literary field explains the genre polyphony of the dialogue with the classical novel, which has become a specific code of contemporary mass culture-from remake to sequel, from comic book to fiction novel, from trash to postmodern fairy tale, from cyberpunk to fanfiction (fanfic).

Keywords: contemporary literature, mass literature, myth, sociology of literature, Anna Karenina, remake, sequel.

DOI: 10.17516/1997-1370-0074.

Research area: philology.

\section{Introduction}

The problem of mass literature in contemporary literary studies is included into the broad context of the sociology of culture and the sociology of literature in particular (Kupina et al. 2009: Chernyak, 2013). Sociological surveys devoted to the studies of the structure of reading in the recent years evidence that the worldview represented by mass literature corresponds to the needs of the representatives of new subcultures and the readers of different ages
(Dubin, Zorkaya, 2008). A change in the status of literature in society inevitably entails a change in the author's and reader's strategies. If formerly the history of the world literature demonstrated the dependence of mass literature on genre and plot findings of elite literature that followed the path of appropriation and adaptation, now the situation is different. Today it is obvious that attention to the works of the "second row" not only expands the cultural horizon, but radically changes optics, as the diversity of mass culture is

(C) Siberian Federal University. All rights reserved

* Corresponding author E-mail address: ma-cher@yandex.ru 
the diversity of the types of sociality. The epoch of relativism supposes a lot of equal approaches to reality. In this connection, the appeal to the problems of mass literature becomes especially urgent and necessary. Being one of the most notable manifestations of modern culture, mass literature remains a theoretically not enough comprehended phenomenon. In the period of social changes, the breakdown of stereotypes and stressful circumstances, a new situation of theoretical comprehension of a new object of research and construction of its universal model arises.

The contemporary reader needs a tool that removes excessive mental tension from the information flows that come down on him, reducing complex intellectual problems to primitive oppositions ("good-bad", "oursstrangers", "good-evill", "crime-punishment", etc.), giving an opportunity to take a rest from social responsibility and the need for personal choice.

F. Moretti offers to "read" large corpus of texts, combining several approaches: quantitative methods, an evolutionary approach to literary forms and a world-system analysis that allows tracing the export of cultural discoveries in the world space (Moretti, 2016: 11). Moretti introduced the phrase "distant reading" by the analogy with the concept of "close reading". With this approach to the history of literature, it is possible to see not the specific features of the style of one or another author, but certain abstract patterns that characterize many texts at once. It appears possible to apply this method to the analysis of author's strategies of the contemporary mass literature.

Moretti considers mass literature as a machine for "removing ambiguity", which seeks to restore the monosemy of sign: "Is there a kind of tacit agreement on the division of labor between mass literature and modernism? If modernism is plunged into abstraction and decomposes the character to complete extinction ("qualities without a man" by Musil), mass literature, on the contrary, strengthens anthropomorphic ideas, filling the world with ghosts and Martians, vampires and great criminals. Modernism rejects the "linear plot" (A. Gide) and the "threads of the story" (Musil) to create immense and unwieldy works; mass literature puts the story in the first place, strives for the ending, gravitates toward short narratives (and, thus, preparing for cinema conventions)" (Moretti: 2016, 11).

\section{Statement of the problem}

"Now, when they say "Russian style", there are only two associations. The first one is Anna Karenina, with sables, the clutch, the fitted fur coat, the tall hat and astrakhan. The second one is connected with Pasternak's "Doctor Zhivago", with revolutionary everyday life, overcoat, with the Red army from the one side and the White army from the other... ", these words of the fashion historian A. Vasilyev fully reflect modern trends in mass culture (Vasilyev, 2012). The kaleidoscope of Anna Karenina's images reflected in glamor can be multiplied, as this image is multiplied in dozens of various foreign and domestic adaptations. Not coincidentally film critic A. Solntseva writes: Anna Karenina "is accompanied by a certain set of scenes. Someone remembers the scene of meeting with Sergei from the film, someone remembers the scene of FrouFrou's death from the school programmes, and certainly everyone remembers what she ended up with death under the locomotive. As well as Chapaev and Stirlitz, she becomes a folklore character; it is possible to write anecdotes about her" (Anna Karenina as a Cultural Phenomenon, 2016). It seems that it is difficult to surprise someone by the games of the contemporary mass culture with classical literature and the complex of new mythologies arising in connection. However, 
the frequency of appeal precisely to L. Tolstoy's novel "Anna Karenina" requires an answer to the question of the reasons for the transformation of the classical work into a certain code of the modern mass culture.

"Classics is always determined by what it is used for", (Compagnon, 2001: 281) noted A. Compagnon, and the existence of Russian classics in the contemporary culture confirms the accuracy of this observation. The transformation of the domestic literary field at the beginning of the $21^{\text {st }}$ century and the reinterpretation of Russian classics boldly reflected the general socio-cultural changes of this period and its dependence on the non-literary context.

Modern philosophers and culturologists have repeatedly noted that activation of the process of myth creation is a kind of reaction to the development of the crisis of existence. "The manifestation and activation of some or other mythologemes are determined by the "reaction" of culture to the changes in the conditions for the society existence; with that mythologemes act as cultural constants. Mythologemes, activated in the culture of the 1990s can be divided into two types. The first type is mythologemes that mark and "start" the processes of annihilation of the obsolescent cultural system ("the patterns of destruction"); the second type of mythologemes means and simultaneously "launches" the processes of the new system synthesizing ("the patterns of revival"). Each mythologeme fixes the specific state of the cultural system and corresponds to a specific tendency of the culture existence (annihilation and constructive respectively). The experience of some or other changes in the cultural system is recorded in the texts based on one or another type of mythologemes", notes philosopher V. Khazov (Khazov, 2009: 4). It seems that the modern interpretation of the image of Anna Karenina paradoxically combines these two types of mythologemes.
“Tolstoy's character, as a point of fact, goes almost only through the most obligatory joys, sorrows and losses, through the "situations", which almost everyone experienced on the way from childhood to maturity", these words by Ya.S. Bilinkis (Bilinkis, 1972: 192) once again prove the invariable relevance of the novel for a wide range of readers and, consequently, the attractiveness of various forms of cultural dialogues and literary games.

The Czech Slavist T. Glanc sees the specific character of Anna Karenina's image in the tension between absolute banality and its incredible relevance: "The uniqueness of this character is precisely in the tension that is hidden in it. On the one hand, this is an absolute banality and the type of conflict and position presenting in any epoch, in any social, political and social context, this is a model situation from the ancient drama or from Shakespeare, from that category. This is one pole of this tension. And the second pole is an absolutely unique implementation of this banal, absolutely simple, not exotic situation" (Anna Karenina as a Cultural Phenomenon, 2016).

Contemporary mass culture intensively produces myths. Mythicalness of consciousness manifests itself in the perception of reality through the stable structures that inevitably generate myths and stereotypes. Adaptation of the novel "Anna Karenina" to the mainstreams of mass literature leads to the language simplification, to the reduction of the depth of symbolic, to the flat sign, to the icon, the smile on the one hand, and on the other hand the main female character of the novel turns into a certain cultural myth. "Myth strengthening in contemporary mass literature is manifested in the fact that it is meaningfully aimed at the exploitation of simple instincts and basic needs and, therefore, especially strongly influence a mass man's consciousness, since instincts are primary in relation to culture" (Maslova, 2007: 212). 
Reflecting on why the plot of "Anna Karenina" is so easily transferred to the mass culture, critic A. Narinskaya notes: "This is just an amazing love story, and this is the main reason why it is mass art that reproduces the story of Anna Karenina. No wonder "Anna Karenina" is subjected to any retelling. <...> I would say that Tolstoy's mastery turned this plot into a pop scheme. It's so well written and so wonderfully tied that it can be used in almost every genre" (Anna Karenina as a Cultural Phenomenon, 2016).

The large mosaic of the contemporary literary field explains the variability in the appropriation of the novel "Anna Karenina" by mass culture. Hence the genre polyphony - from remake to sequel, from comics to a fantastic novel, from trash to postmodern tale, from cyberpunk to fanfic.

In Yu.M. Lotman's conception culture is developed in the change of states of "decline", "acceptance" of other's texts and rise, active "translation" of their own original works (Lotman, 2000). In the phase of decline passive saturation is taking place, where the texts are adapted. When saturation reaches a certain threshold, internal mechanisms of text generation of the receiving structure are set in motion. From the passive state it goes into the state of agitation and starts vigorously allocating new texts itself, bombarding other structures including its "launcher" with them. It can be claimed that Tolstoy's novel has become such a "launcher" of text generation for contemporary mass culture.

One of the favorite genres of mass literature, which is the result of the classical text processing, is remake that, according to $\mathrm{M}$. Zagidullina words,"is a faithful slave of the classics, that puts his back to step over it into the future" (Zagidullina, 2004: 214). The purest experiment to destroy the context of the epoch that represented a combination of the background knowledge, is reflected in the remake by Lev Nikolaev "Anna Karenina", in which the tragedy of the female character is reduced to the level of banal adultery.

It is known that critic A. Stankevich called his article about the work by L.N. Tolstoy "Karenina and Levin. Two Novels", claiming that the writer "wrote not one, but two novels". Tolstoy's modern epigone shortens the text exactly "for one novel", explaining it in the announcement in the following way: "The new "Anna Karenina" is a reflection of only one of the storylines of the old novel, the most famous and the most irrational one. Scrupulously following the original I, nevertheless, was sometimes forced to retreat from it. As I told Anna's story in such a way as if it has taken place now. The main thing is still the story of the woman. And about the basic instinct (italics added by the author M. Ch.)" (Nikolaev, 2001: 5).

Decoding of the work is carried out in a simple way: while preserving the main storylines and the names of the characters (in some cases they are only modernized: Dolly $\rightarrow$ Dasha, Kitty $\rightarrow$ Katya), the text is shortened and simplified, and in many text fragments Tolstoy's text is reproduced almost verbatim. The elements of the lexical structure of the text are adapted to the reflection of the modern reality (often at the level of naive consciousness): Stiva woke up at eight o'clock in the morning, not in his wife's bedroom $\rightarrow$ Stepan Arkadyevich woke up at seven in the morning not in the bedroom; French governess $\rightarrow$ English teacher; inn $\rightarrow$ hotel; rooms $\rightarrow$ the room; children ran around the house $\rightarrow$ children ran around the huge apartment of the Moscow skyscraper; potentially agnomic for the modern reader lexicon is replaced or even excluded from the text: Moroccan sofa $\rightarrow$ leather sofa; proper names are replaced by the names current for the modern reader: Darmstadt $\rightarrow$ Davos; the replacement of the precedent texts has taken place: Il mio tesoro $\rightarrow$ "I am your little bunny!" 
As a result of such substitutions, a new vertical context is not created, some markers of the epoch remain only the labels of everyday life. Compare: in Anna Karenina by L. Nikolaev: "last year's default", the Porsche supercar, the box of "Korkunov", glossy magazines, "Karenin was an important person in Smolny", Levin in the province "has been doing something like "developing Russia" in accordance with Solzhenitsyn", "Vronsky went to the Leningradsky railway station", "Vronsky found a message from Anna on his answering machine", Karenin reads Fomenko's "History", Anna cries over the film "Titanic", etc.

"Orientation to the addressee determines a special nature of the signals used by the author. These signals heats the reader's imagination, evoke the images of the corresponding situation", writes N.S. Bolotnova (Bolotnova et al., 2001: 67), however, in the transformations similar to the above mentioned, the image of the mass reader on whom the author is oriented certainly excludes any orientation on the multidimensional text space creation and does not imply the actualization of the reader's imagination.

Lilia Kim' remake "Anya Karenina" is characterized by the author as: "A cheap literary production 100 years later, but on the scale of the modern epoch, when there are much more people and, therefore, each of them occupies a much smaller living space. Not palaces, but Khrushchevera apartment. Not bored noblemen, but proletarians without a place. Plastic instead of wood and stone. Tolstoy's names have become something like control marks, so that everyone can understand and feel the scale of change. They create an internal dialectics of the text" (Kim, 2005: 288). Having placed the Karenin-Oblonsky family into a cramped tworoom apartment in one of the residential areas of St. Petersburg, L. Kim uses the genre of trash, which is characterized by the complete negation of the generally accepted norms.
The novel by Elena Kolina "Clever Girl, Beautiful Girl" is "the story of the contemporary Anna Karenina, our close friend (italics added by the author - M. Ch.), clever and beautiful; an exciting story that makes you think your own, personal thoughts". This is an indicative example of a remake in which characters recognize themselves within a classic story, and the dialogue with the praetexta generates a special type of literary utterances. Compare: "I, as well as Anna, go to Moscow to settle family affairs of my brother. All the way, I am having a nice talk with Mouse. Mouse will go for Countess Vronskaya. Mouse's son is called Alexei, as Karenin and Vronsky. My husband's name is also Alexei. Oh!... Anna meets Vronsky at the station, and the passion begins..." (Kolina, 2006: 77). Sonya's favorite novel is Anna Karenina, and they have a special affinity with Knyazev for the fact that both of them had a portrait of L.N. Tolstoy that hung over their beds in the childhood, "They laughed, having found out that they both grew up under Tolstoy's portraits, Knyazev under a white cardboard portrait from the school set "Great Russian Writers", Sonya under his photograph in Yasnaya Polyana" (Kolina, 2006: 99). In Anna Karenina, the "family idea" solves the problem of reconciliation of the extremes of selfishness and self-denial, the "personal good" and the "common good" and, to a certain extent, removes the contradiction between the attainability and the unattainability of the ideal. Sonya Golovina, being stronger than her literary predecessor, after going through all the trials, chooses her family.

The special optics of the Tolstoy's novel rereading is fairly representative in sequels, the works that continue the storyline of the classical text. Thus, the storyline of the retro detective by Anton Chizh "Dangerous Surname" is connected with the fact that a famous retired official Alexei Karenin and a ballerina who worked at the Imperial Theater were killed in St. Petersburg, and 
both of them were found in the house of the son of the official Serge Karenin. Detective Vanzarov (A. Chizh's serial character) faces a series of deaths that occurred exactly 20 years after Anna Karenina's death (Chizh, 2013). Throughout the novel Anna Karenina is represented as a ghost that appears to the characters. Mysterious crimes that gradually occur with all the characters of the Tolstoy's novel make to re-read the classical work in a new way.

Film director S. Solovyov, the author of one of the cinematographic interpretations of Tolstoy's novel with Tatyana Drubich as Anna Karenina, reflecting on the constant relevance of this work, expresses a very interesting idea: "This is the best novel of the Silver Age, written when the Silver Age was still not in sight, it had not begun yet, it was not even supposed to. But the best novel of the Silver Age had already been outlined by Tolstoy. As the ideology, aesthetics and beauty of the Silver Age are fully embodied in it. And why is Anna Karenina of interest now? Because, figuratively speaking, Akhmatova-Tsvetaeva's consciousness is the most perfect unicum, the spiritual core of the woman's consciousness of the $20^{\text {th }}$ and the $21^{\text {st }}$ centuries. The best women have remained Annas Karenina, not all of them with a terrible ending of their spiritual and all sorts of other searches, but all with such a soul" (Anna Karenina as a Cultural Phenomenon, 2016).

A fantastic story by Dmitry Romanovsky " $M y$ privilege to introduce - Anna Karenina", starting with the death of Anna under the wheels of the train can be an original illustration of Solovyov's words. But the female character of the story is not Anna Karenina, but Anna Kuptsova, our contemporary, who is in the hospital and rereads the Tolstoy's novel not as a literary work, but as the pages of her own life. She is a programming specialist who works with neurophysics, to which the cassettes with the recording of the image of the Tolstoy's female character" were connected.
"In two hours Anna Kuptsova became Anna Karenina" (Romanovsky, 2013). "Everyone who has read Anna Karenina, from naive readers to professional researchers, have one, common for all impression, formulated by K. Leontiev: "The one who studies Anna Karenina studies the life itself. Everyone speaks about the special effect of Anna Karenina's life similarity" (Slivitskaya, 2002: 45).

According to L. Fiedler, the unity of the writer and the reader is facilitated by blurring the boundaries between "mass character" and "elitism". Fiedler calls the author a "double agent" that represents "elitist" in the "mass", and "mass" in the "elitist" (Fiedler, 1993, 66). What Yu.M. Lotman called "switching from one system of semiotic awareness of the text to another" (Lotman, 2000: 543) is taking place in the postmodernist play by Oleg Shishkin "Anna Karenina-2". "We have not noticed how the speed of movement and the speed of obtaining information reflected our ethics and the attitude towards our neighbor", the author says in the foreword to the play. "Tolstoy captured the situation intuitively and created "Anna Karenina", a work not only about tragic love, but also about the new morality generated by locomotives and the telegraph" (Shishkin, 2016). Having survived under the wheels of the locomotive Shishkin's Anna Karenina becomes disabled. At the end of the play Senator Karenin takes his wife to a new French attraction called the "cinema". "The Arrival of the Train" was shown at the "cinema": the silhouette of a lady with high raised arms, a red velvet handbag on her wrist trembles against the background of the Lumiere brothers' invention, against the background of the chronicles of the First World War and the Civil War, against the background of black and white ruins and echelons, tank parades on the Red Square, etc. As a result, Shishkin's Anna is killed by the cinema, she could not survive "The Arrival of the Train" 
by the Lumiere brothers. The illusion of the $20^{\text {th }}$ century was overcome by the reality of the $19^{\text {th }}$ century.

Postmodernist aesthetics, according to U. Eco, rehabilitates repetition, at that at this stage "not separate variations, but "variability" as a formal principle is of interest, the very fact of what can be varied to infinity. This infinite variability has all the characteristics of repetition and only partly of innovation. But it is this "infinity" of the process that gives a new meaning to the method of variation" (Eco, 1996: 87). Contemporary postmodernists actively master the role of "double agents", including in their plays with classics. In this case, the postmodernist fairytales by Lyudmila Petrushevskaya "The Beard of Anna Karenina" and "Anna Karenina", which are included in the cycle "Borderline Tales About Kittens", are indicative. "Borderline Tales About Kittens" is a series with ordinary characters, who have common for the reader names (grandfather Seryozha Shvarts, Anna Karenina, Mumu, etc.).

As T. Prokhorova notes, "Petrushevskaya's creative work resembles a kind of laboratory where new and old genres are tested, where experiments with different styles are conducted, where realism is intersected with postmodernism, naturalism with sentimentalism, etc. Everything here is permeated with the currents of dialogueness, and the most diverse layers of national and world culture: folklore tradition, mythology and classical literature are involved in the game of dialogue" (Prokhorova, 2009: 149). The fairytales about Anna Karenina by Petrushevskaya refer us to the illogical anecdotes by Daniil Kharms, in which the actions of wellknown literary and historical characters are not determined by anything, they are not motivated and do not require an explanation: "We have news: Anna Karenina has come (the very same, from the work of Leo Tolstoy) and informed us that she has a local beard" (Petrushevskaya,
2008: 88). The choice of the recognizable names of Russian literature creates an absolutely transparent connotation. Reducing the image to an almost blasphemous mockery, the parody is on the verge of a foul ("Here we had something, Anna Karenina came to visit us, it looks like everything is fine, she sits, crisps with cat food, and then she asks if we have a railway timetable" (Petrushevskaya, 2008: 111)), demonstrating the vitality of the ambivalent consciousness and the shocking nature of carnivalization (displacement of "high-low", "sacral-profane"). The literary world of Petrushevskaya is a flexible and unpredictable phenomenon. Not only realistic and postmodernist, but also sentimental, baroque, romantic, naturalistic and modernist intentions are intertwined it is.

"Postmodernism is the transition to a state where the reader becomes a free interpreter and when the writer does not slap him on the wrist and does not say "you read it in a wrong way, read it differently", is the moment of liberation, and in this sense postmodernism today is the achievement of freedom in literature" (Erofeev, 1997: 88). These words of V. Erofeev explain the interest of postmodernism to the phenomena of mass culture, which is connected with the fact that mass literature as a kind of resonator of sociocultural processes expands the range of modern culture and creates conditions for diagnosing experimental trends in the development of modern literature.

Sequel novel "Anna Karenina-2" by Alexander Zolotko is a grotesque, sometimes absurd and sometimes sad story of the literary characters' "life" in the real world (Zolotko, 2013). The female character of this postmodern pastiche that sometimes takes the shapes of a huge literary crossword puzzle, is Anya Karenina, the daughter of Anna and Vronsky, who after having accidentally read the novel by Leo Tolstoy strives to know as much truth about her mother 
as possible and avenge for her. Thus, she finds her father Vronsky, who quietly loses himself into drinking in the county town of Simbirsk, having seduced Katyusha Maslova from Rodion Raskolnikov. There are other characters of Russian and world classical literature in the novel by Zolotko: from Sergei Paratov to Ostap Bender, from Sherlock Holmes to Grigory Melekhov. The author's fantasy confronts historical figures (Chekhov, Stanislavsky, Kerensky, Lenin, Kaplan, etc.) with literary characters literally on every page. The relationship between the author and the characters and the responsibility of the former to the latter are the main theme of the novel (for example, through the whole novel there is a storyline of doubts and reflections of Sherlock Holmes's assistant who still cannot understand who he really is - the character Dr. Watson or the writer Conan Doyle). Literary characters feel like puppets in the writer's hands, the writers suffer from the fact that they create monsters that they are haunted by later (for example, Tolstoy receives letters from Anna with the threats of murder and flees from Yasnaya Polyana in fear of them).

In modern Russia, under the conditions of the loss of literary centrism and the dominance of mosaic thinking, comics are becoming more popular. The reason for this lies in the easily readable form, and a simple picture refers to the archaic consciousness. The phrases of comics, enclosed in "bubbles" or bubble clouds, are simple, concise and contrast with the texts of "high genres". The discrete, mosaic form of graphic texts is adequate to the modern rhythm of life. L. Gorlova notes: "Comics, as well as the daily flow of news on the Internet can be reproduced endlessly, varying as a construction kit with a certain limited set of semantic modules" (Gorlova, 2010). In the comics "Anna Karenina by Leo Tolstoy", created by Katya Metelitza and painted by V. Kachaev and I. Sapozhkov, "psychedelic drama with the elements of cyberpunk" is embodied, the action is transferred to our time. The frames formation is done with linear translation into English, which refers the reader to the tradition of American comics about superheroes. The comics "Anna Karenina by Leo Tolstoy" retains all the original dialogues of the classical text in most frames, but it is completely devoid of the authors' deviations. It is possible to talk about the creation of a new work, distanced from the original source and, at the same time, complementing it.

Fanfiction is a qualitatively new type of literature, which opens up ample opportunities for analyzing interpretative features and changing the ratio of "author-text-reader". Fanfic can be a continuation, a prehistory, a parody, an "alternative universe", a crossover ("interweaving" of several works), etc. The presence of fanfics for a certain fandom is indicative of the popularity of the classic work among the mass reader. For instance, on one of the largest resources of the Russian Internet dedicated to fan fiction, thirty-five fanfics of various genres, sizes and ratings were found on the "Anna Karenina" fandom, which evidences of the unprecedented popularity of the Tolstoy's novel. Based on the content of the fanfics it is possible to trace the tendencies which the contemporary ficwriter follows. Fanfics are usually limited to one chapter, a kind of the readers" "sketch" who wants to share their impressions. The most popular episode of the novel for ficwriters is, of course, the scene of Anna's suicide.

Noting the special importance of intertextual roll calls in contemporary literature, M. Epshtein writes: "Now the quotation marks have absorbed into the flesh of each word so much, that the word itself, without the quotation marks, has the aftertaste of its secondary nature, which has become simply necessary to feel the freshness of its repeated use" (Epstein, 2000: 281). Although, it must be said that sometimes such 
"freshness of the repeated use" gives rise to other meanings. "All the working robots are alike, each faulty robot is faulty in its own way", it is the beginning of the book by the American writer Ben Winters "Android Karenina", written in the style of cyberpunk (Winters, 2011: 3). Winters puts Tolstoy's characters into a fantastic world of robots and cars, in which robots declare war against people. To achieve aesthetic effect (the "feeling of freshness from the repeated use"), the reader should at least have textual competence. The fact that the elite reader differs from the mass one not by selecting texts, but by the ability to comprehend any of them critically cannot be ignored. In its aesthetic competence there are also "trivial, fundamental, and transitional texts, those in which intellectual content can be hidden behind the simplicity of forms, or those in which a complex style structure is not supported in the content plane. The mass reader is a poorer interpreter: their literature is only trivial texts and the "trivial layer" in transitional patterns" (Markasova, 2001, 119).

It is indicative that the storyline of the first "computer" novel "[True Love]*. Wrt. The Perfect Novel" was again a love collision of the main characters of "Anna Karenina". The book is in the manner of Haruki Murakami, the style is based on vocabulary, linguistic means and techniques of 13 Russian and foreign authors of the $19^{\text {th }}-21^{\text {st }}$ centuries. To create the text of the novel, a group of programing specialists and philologists created the program PC Writer 2008. The philologists collected a dossier for each of the novel's characters, which included description of their appearance, vocabulary, psychological portrait and other characteristics, a description of the initial situation, on the basis of which the programme generated the text of the novel was created.

Among many projects for "appropriating" the novel "Anna Karenina", a project created by the staff of the Yasnaya Polyana Museum and the campaign of Google and Samsung "Karenina. Live Edition", aimed at demonstrating the continuous interest of a wide range of readers to the novel can be called mass culture. For 36 hours without a break more than 800 people around the world (actors, teachers, students, librarians, officials, museum workers, scientists and just fans of Leo Tolstoy's creative work) were reading "Anna Karenina", discovering unexpected facets of the classical text.

\section{Conclusion}

Skepticism about "re-reading" the classics and its modernization dictated by the worshipping the symbolic status of the classic author is characteristic of a lot of modern readers who see "desecration of the shrine" behind technical innovations, playing with cultural codes and dismantling the previous contexts. Thus, for instance, writer S. Zalygin in the late $20^{\text {th }}$ century said with conviction that "all classical works are the personalities of their creators, exclusive and unique, they can and should be studied, they can and must be read thoroughly, but it is impossible to "reread" them with one's own voice, on one's own taste and mind, and abridge in addition, and even supplement, and then to present this "reading" as one's own creativity and achievement, this is not art, but rather anti-art. Tolstoy himself had the right and could re-read Tolstoy in this way, and he did it, but again we get into a thorough reading of his own re-reading" (Zalygin 1991: 391). However, the above examples show that the process of "rereading" of Tolstoy's novel "Anna Karenina" under conditions of new challenges of the time, new myths, new contexts and new cultural landmarks can not be stopped.

The basis of each cultural epoch is formed by its own generating mechanism. In one of the interviews the writer M. Shishkin, insisting that "today it is impossible to write in a way as they 
wrote in the $19^{\text {th }}$ or $20^{\text {th }}$ century", convincingly noticed that the real writer "should write his/ her Anna Karenina" (italics by the author - M. Ch.), using all the achievements of the world literature that were before and after Tolstoy. The human essence remains, and there will always be need for love as in the times of "The
Song of Songs", but "Anna Karenina" of the $21^{\text {st }}$ century will be written in a completely different way" (Shishkin, 2010). Various examples of the Tolstoy's novel privatization by the modern authors are kinds of literary oxymorons, recreating the matrix of modernity in their own way.

\section{References}

Anna Karenina kak kul'turnyi fenomen i geroinia massovoi kul'tury. K 100-letiiu so dnia ukhoda L'va Tolstogo [Anna Karenina as a Cultural Phenomenon and the Female Character of Mass Culture. To 100 th Anniversary of Leo Tolstoy's Death] (2016). [Electronic source], available at: http://www. svoboda.org/a/2243474.html (accessed 26.11.2016)

Bilinkis, Ya. S. (1972). Anna Karenina L.N. Tolstogo i russkaia literatura 1870-kh godov ["Anna Karenina" by L.N. Tolstoy and Russian Literature of the 1870s]. L., Nauka, 192 p.

Bolotnova, N.S., Babenko, N.I., Vasil'eva, A.A. et al. (2001). Kommunikativnaia stilistika khudozhestvennogo teksta: leksicheskaia struktura i idiostil' [Communicative Stylistics of Fictional Text: Lexical Structure and Individual Style]. Tomsk, TSPU Publishing House, 287 p.

Vasilyev A. (2012). Gran' mezhdu muzhchinoi i zhenshchinoi stiraetsia [The Distinction between Man and Woman is Blurred] [Electronic source] - URL: http://riatribuna.ru/news/2012/02/09/11804/ (accessed 16.10.2016).

Gorlova, L. (2010). Komiks kak sistema kodov [Comics as a Code System], In Isotekst: stat'i i komiksy [Isotext: Articles and Comics]. M., Russian State Library for Young Adults. 226 p.

Erofeev, V. (1997). Interv'iu [Interview], In Postmodernisty o postkul'ture: Interv'iu s sovremennymi pisateliami i kritikami [Postmodernists about Postculture: Interview with Contemporary Writers and Critics] (Edited by S. Roll). M., 178 p.

Zagidullina, M. (2004). Remeiki ili ekspansiia klassiki [Remakes or the Classics Expansion], In Novoe literaturnoe obozrenie [New Literary Observer], 69, 213-222.

Zalygin, S.P. (1991). Pisatel' i traditsiia [Writer and Tradition], In Zalygin S.P. Sobr. Soch. $v 6 t$. [Zalygin S.P. Collected Works in 6 volumes]. M., Khudozhestvennaia literatura, 6, 390-401.

Zolotko, A.K. (2013). “Anna Karenina-2” [Anna Karenina-2]. M., Al'kor Publishers, 480 p.

Dubin, B.V., Zorkaya, N.A. (2008). Chtenie v Rossii - 2008. Tendentsii i problemy [Reding in Russia - 2008. Tendences and Challenges]. M., Interregional Library Cooperation Centre, $80 \mathrm{p}$.

Kim, L. (2005). Ania Karenina. Kniga vtoraia. [Anya Karenina. Book Two]. SPb., "Neva" Publishing House, 288 p.

Kolina, E. (2009). Umnitsa, krasavitsa [Clever Girl, Beautiful Girl]. M., Amphora, 288 p.

Compagnon, A. (2001). Demon teorii [The Tamed Demon of Theory]. M.: The Sabashnikovs' Printing House, 336 p.

Kupina, N.A., Litovskaya, M.A., Nikolina, N.A. (2009). Massovaia literatura segodnia: Uchebnoe posobie [Mass Literature Today: Study Guide]. M., Flinta: Nauka, 424 p.

Lotman, Yu.M. (2000). Semiosphera. Kul'tura i vzryv. Vnutri mysliashchikh mirov [Semiosphere. Culture and Explosion. Inside the Thinking Worlds]. SPb., Iskusstvo, 704 p. 
Markasova, O.A. (2001). Teksty massovoi literatury v kognitivnom aspekte [Mass Culture Texts in Cognitive Aspect], In Problemy interpretatsionnoi lingvistiki: avtor-tekst-adresant [Problems of Interpretational Linguistics: Author - Text-Addresse]. Novosibirsk, Nauka, 256 p.

Maslova, S.V. (2007). Funktsionirovanie mifa v sovremennoi kul'ture: kontekst perekhoda k ratsional'nosti postmoderna [Myth Functioning in Modern Culture: the Context of Transition to Postmodernitism Rationality], In Izvestiia Tomskogo politekhnicheskogo universiteta [Bulletin of Tomsk Politechnic University], (310), 2, 211-214.

Moretti, F. (2016). Dal'nee chtenie [Distant Reading]. M., Gaidar Institute Publishing House, $352 \mathrm{p}$.

Nikolaev, L. (2001). Anna Karenina [Anna Karenina]. M., Zakharov, 303 p.

Petrushevskaya, L. (2008). Pogranichnye skazki pro kotiat [Borderline Tales About Kittens]. SPb., Amphora, 296 p.

Prokhorova, T.M. (2009). Rasshirenie vozmozhnostei kak avtorskaia strategiia. Lyudmila Petrushevskaya [Broadening Options as Author's Strategy. Lyudmila Petrushevskaya], In Voprosy literatury, 3, 149-164.

Romanovsky, D. (2013) Chect' imeiu predstavit' - Anna Karenina [My privilege to Introduce Anna Karenina]. [Electronic source], available at:: http://modernlib.ru/books/romanovskiy_dmitriy/ chest_imeyu_predstavit_anna_karenina/read/ (accessed 12.10.2016)

Slivitskaya, O.V. (2002). Ob effekte zhiznepodobiia v “Anne Kareninoi”: ritm kompozitsii [On Life Similarity Effect in Anna Karenina: Composition Rhythm], In Russkaia literatura [Russian Literature], 2, 28-50.

Winters, B. (2011). Android Karenina [Android Karenina]. SPb., Astrel', Corpus. 768 p.

Fiedler, L. (1993). Peresekaite rvy, zasypaite granitsy [Cross the Border, Close the Gap], In Sovremennaia zapadnaia kul'turologiia: samoubiistvo diskursa [Modern Western Culturology: Discourse Suicide]. M., 233 p.

Khazov, V.K. (2009). Mifologemy rossiiskoi kul'tutry postsovetskogo perioda (1990-e gody): filosofskii analiz [Mythologems of Russian Culture of the Post-Soviet Period (the 1990s)]: Philosophical Analysis. Synopsis of Thesis for the Scientific Degree of Candidate of Philosophical Sciences. Astrakhan, $22 \mathrm{p}$.

Chernyak, M.A. (2103). Massovaia literatura XX veka: Uchebnoe posobie [Mass Literature of the 20th Century: Study Guide]. M., Flinta: Nauka, 432 p.

Chizh, A. (2013). Opasnaia familia [Dangerous Surname]. M., Eksmo, 267 p.

Shishkin, M. (2010). "Napisat' svoiu Annu Kareninu..." [“Write Own Anna Karenina...”]. [Electronic source], available at:: http://9tv.co.il/news/2010/12/05/89804.html (accessed 13.05.2016)

Shishkin, O. (2016). Anna Karenina 2 [Anna Karenina 2]. [Electronic source], available at:: $<$ http://www.theatre-library.ru/files/sh/shishkin_oleg/shishkin_oleg_1.html $>$ (accessed 13.05.2016)

Eco, U. (1996). Innovatsiia i povtorenie: Mezhdu estetikoi moderna i postmoderna [Innovation \& Repetition: Between Modern \& Postmodern Aesthetics], In Filosofiia epokhi postmoderna: sb. perevodov i referatov [Postmodernism Era Philosophy: Collection of Translations and Reports]. Minsk, Krasiko-print, 52-73.

Epstein, M. (2000). Postmodern v Rossii. Literatura i teoria [Postmodernism in Russia. Literature and Theory]. M., R. Elinin Publishing House. 368 p. 


\title{
Массовая литература
}

\section{как экспериментальная площадка \\ авторских стратегий:}

случай Анны Карениной

\author{
М.А. Черняк \\ Российский государственнылй \\ педагогический университет \\ им. А.И. Гериена \\ Россия, 191028, Санкт-Петербург, \\ наб. реки Мойки, 48
}

\begin{abstract}
Статья посвящена анализу репрезентативных авторских стратегий, реализуемых в современной российской массовой литературе. В ситуации утрать русской культурой принцииа литературоиентризма анализ разных способов присвоения классического текста массовой литературой приобретает особую актуальность. В статье рассматривается феномен игры современного масскульта с классической литературой и возникающчй в связи с этим комплекс новых мифологий, выявляются причины частотности обращчения к роману Л. Толстого «Анна Каренина». Большая мозаика современного литературного поля объясняет жанровую полифонию диалога с классическим романом, который стал определенным кодом современного масскульта - от ремейка до сиквела, от комикса до фантастического романа, от треша до постмодернистской сказки, от киберпанка до фанфика.
\end{abstract}

Ключевые слова: современная литература, массовая литература, миф, сочиология литературы, Анна Каренина, ремейк, сиквел.

Научная специиальность: 10.00.00 - филологические науки. 